\title{
Virus-Associated Hemophagocytic Syndrome
}

National Cancer Institute

\section{Source}

National Cancer Institute. Virus-Associated Hemophagocytic Syndrome. NCI Thesaurus.

Code C162686.

Hemophagocytic syndrome that is associated with viral infection. 